\title{
PEMANFAATAN MEDIA ONLINE SEBAGAI MEDIA SARANA KOMUNIKASI DALAM MEMENUHI KEBUTUHAN INFORMASI AKADEMIK PADA KALANGAN MAHASISWA INSTITUT ILMU SOSIAL DAN ILMU POLITIK (IISIP) YAPIS BIAK
}

\author{
Rahmah Agustiani \\ Program Studi Ilmu Komunikasi, Fakultas Ilmu Sosial dan Ilmu Politik \\ Institut Ilmu Sosial dan Ilmu Politik YAPIS Biak \\ Email : RahmaAgustiani13@gmail.com
}

\begin{abstract}
Abstrak
Media online dan kegiatan akademik tidak dapat dipisahkan. Akademisi sekarang menggunakan media online untuk mendukung kegiatan akademik. Terlepas dari waktu benar atau tidak menggunakannya. Dan tidak terkecuali dengan mahasiswa di IISIP Yapis Biak. Penelitian ini akan membahas bagaimana mahasiswa IISIP Yapis Biak menggunakan media online untuk memenuhi kebutuhan informasi akademik mereka. Penelitian ini akan dilakukan dengan wawancara informan mendalam dari perguruan tinggi Institut Ilmu Sosial dan Ilmu Politik (IISIP) Yapis Biak. Setelah data yang telah diperoleh akan dibedah menggunakan penggunaan teori dan gratifikasi teori terutama di depan umum teori kebutuhan. Penelitian mendalam akan menjelaskan media online setiap yang digunakan dalam mendukung informasi akademik. kebutuhan seperti apa yang mereka cari, dan apa yang membuat mereka merasa terpenuhi kebutuhan mereka dalam penggunaan media online, terutama untuk membutuhkan informasi akademik. Hasil penelitian tentang bagaimana menggunakan media online sebagai sumber informasi akademik mahasiswa Institut Ilmu Sosial dan Ilmu Politik (IISIP) Yapis Biak menunjukkan bahwa sebagian besar siswa mengakses media online sebagai sumber informasi akademik. ini dapat dilihat dari sebagian besar responden menjawab menggunakan media online sebagai sumber informasi dalam mencari akses informasi akademik, siswa lebih efektif dibandingkan dengan kualitas karena sumber informasi yang dikenal di media online tidak semua benar, itu menjadi satu-satunya kendala bagi mahasiswa dalam mengakses media online
\end{abstract} Kata Kunci: Penggunaan, Media Online, Informasi Akademik.

\section{PENDAHULUAN}

A. Latar Belakang

Perkembangan media online tentu saja tidak dapat dilepaskan dari pengaruh internet. Sebuah sistem sederhana yang saling menghubungkan tiap-tiap data yang ada dalam sebuah server kemudian ditransmisikan dengan ribuan kilometer kabel yang terbentang diseluruh dunia yang kemudian data tersebut dapat dengan mudah dikonsumsi didepan komputer pribadi masing-masing. Penemuan ini mengubah siapapun dalam mencari informasi.
Pengguna media online tidak dapat diaturdalam tata cara penggunaannya. Mereka memiliki kuasa penuh atas apa yang mereka konsumsi setiap hari, mereka akan fokus mencari apa yang mereka butuhkan tanpa perlu permisi atau bahkan tidak perlu jauh-jauh datang ke sebuah daerah atau negara untuk mendapatkan berita yang mereka inginkan. Aktivitas belajar dan mengajar pun kini sudah terpengaruhi dengan kehadiran media online. Sebagian besar orang dalam lingkup akademisi 
menggunakan media online dalam kesehariannya.

Pada awalnya orang memperoleh pengetahuan dengan cara yang belum dapat dipercaya. Namun secara perlahan sesiring dengan perkembangan jaman, seseorang mulai menggunakan teknologi. Dengan kemampuan dan akalnya manusia ingin keluar dari masalah, ingin hidup lebih baik, lebih aman, mudah, dan nyaman. Perkembangan teknologi terjadi karena seseorang menggunakan kemampuan dan kecerdasan akalnya untuk menyelesaikan setiap masalah yang dihadapinya. Teknologi Informasi adalah suatu teknologi yang digunakan untuk mengolah data, termasuk memproses, mendapatkan, menyusun, menyimpan, memanipulasi data dalam berbagai cara untuk menghasilkan informasi yang berkualitas, yaitu informasi yang relevan, akurat dan tepat waktu, yang digunakan untuk keperluan pribadi, pendidikan, bisnis, dan pemerintahan dan merupakan informasi yang strategis untuk pengambilan keputusan. Teknologi informasi dan komunikasi (TIK) merupakan suatu hal yang tidak asing lagi bagi kalangan masyarakat. Teknologi Informasi dan Komunikasi pada masa sekarang ini memegang peranan penting, baik dalam bidang Pendidikan, ekonomi, sosial, budaya, geografi, agama, dan juga berbagai bidang lainnya. Teknologi Informasi dan Komunikasi merupakan suatu hal yang bisa dijadikan sarana untuk menunjukkan maju atau tidaknya suatu negara. Teknologi Informasi dan Komunikasi dipandang sebagai suatu hal yang dapat mengangkat citra bangsa, negara-negara di dunia berlomba-lomba untuk memajukan teknologi, informasi dan komunikasi.

Di Indonesia, semakin banyak mahasiswa, professor, ilmuwan dan lainnya turut serta mengembangkan Teknologi Informasi dan Komunikasi di Indonesia. Teknologi informasi dan Komunikasi dipandang sangat penting untuk dikembangkan di Indonesia, penyebabnya karena bangsa Indonesia tertinggal oleh bangsa-bangsa lain salah satunya adalah karena minimnya perkembangan Teknologi Informasi dan Komunikasi di Indonesia. Kebanyakan bangsa kita lebih senang memanfaatkan Teknologi Informasi dan Komunikasi, tetapi tidak banyak yang berminat untuk bisa menguasai dan mengembangkannya. Melihat dari uraian diatas, maka sudah seharusnya bangsa Indonesia berusaha untuk bangkit dan berkembang. Sebenarnya bangsa Indonesia mempunyai banyak pemuda yang mempunyai bakat dalam bidang Teknologi Informasi dan Komunikasi, akan tetapi karena mungkin keterbatasan biaya, maka mereka menjadi kurang bersemangat untuk mengembangkannya.

Namun terkendalanya masalah tersebut, tidak menghentikan inisiatif untuk meningkatkan literasi Teknologi Informasi dan Komunikasi telah terlihat dilakukan oleh semua pihak; mulai dari pemerintahan, perguruan tinggi, lembaga pendidikan, swasta, dan masyarakat (individual). Seminar tentang internet, roadshow, pengenalan internet di sekolahsekolah merupakan kegiatan yang umum dilakukan. Hal ini juga didukung jumlah penduduk Indonesia yang banyak dan karakteristik orang Indonesia yang memiliki sifat kreatif dan moderat. Orang Indonesia lebih senang pulang kampung setelah pekerjaan selesai. Bagi pemberi pekerjaan di luar negeri, hal ini merupakan factor yang penting karena nantinya tidak memberatkan mereka dengan urusan penduduk baru (imigran). Banyak professional dan pendidik Indonesia yang 
lulusan perguruan tinggi di luar negeri. Mereka memiliki kemampuan yang sama dengan koleganya di luar negeri.

Di dalam dunia pendidikan, peran IT atau teknologi informasi dan komunikasi dijadikan nilai mutlak ynag harus dikuasai untuk menyambut era globalisasi dengan persaingan kemajuan teknologi yang pesat. Dahulu, seseorang harus berkelana atau berjalan untuk menemui pakar untuk mendiskusikan sebuah masalah. Saat ini, hal ini dapat dilakukan dari rumah dengan menggunakan alat komunikasi seperti telepon atau dengan mengirimkan email. Makalah dan penelitian dapat dilakukan dengan saling tukar menukar data melalui internet, via email, ataupun dengan melanisme file sharring. Sharring informasi juga sangat dibutuhkan dalam bidang penelitian agar penelitian tidak berulang (reinvent the wheel). Hasil-hasil penelitian di perguruan tinggi dan lembaga penelitian dapat digunakan bersamasama sehingga mempercepat proses pengembangan ilmu dan teknologi. Bagi Indonesia, manfaatmanfaat yang disebutkan diatas, sudah menjadi alasan yang kuat untuk menjadikan teknologi dan internet sebagai infrastruktur dibidang pendidikan. Untuk merangkumkan manfaat internet bagi pendidikan di Indonesia: akses ke perpustakaan, akses ke pakar, menyediakan fasilitas kerja sama. Perkembangan Teknologi Informasi dan Komunikasi.

Internet menjadi salah satu alternatif yang digunakan oleh mahasiswa selain perpusatakaan. Ketiadaan buku atau referensi di perpustakaan menjadi salah satu faktor yang memungkinkan mahasiswa untuk mencari jalan mudah untuk menemukan informasi akademis yang cepat dan mudah. Jika ingin mencari buku di perpustakaan umumnya mahasiswa harus mencari buku tersebut di rak-rak yang sudah memiliki kode sesuai dengan klasifikasi yang ditentukan, selanjutnya baru mencari bagian-bagian yang dicari untuk kemudian dibaca atau ditulis ulang. Berbeda dengan cara pencarian informasi pada media online, kita cukup memasukan kata kunci yang diinginkan pada salah satu mediaonline yang kita gunakan, maka akan muncul begitu banyak hasil pencarian yang kita inginkan.

\section{B. Rumusan Masalah}

Berdasarkan latar belakang yang telah diuraikan maka pada penelitian ini peneliti ingin mengetahui :

1. Bagaimana penggunaan media online dikalangan mahasiswa INSTITUT ILMU SOSIAL DAN ILMU POLITIK (IISIP) YAPIS BIAK. dalam memenuhi kebutuhan informasi akademik?

2. Penggunaan media online apa saja yang menjadi sumber informasi akademik di kalangan masiswa IISIP Yapis Biak?

\section{Tujuan Penelitian}

Penelitian ini bertujuan untuk mengetahui bagaimana penggunaan media online mahasiswa INSTITUT ILMU SOSIAL DAN ILMU POLITIK (IISIP) YAPIS BIAK. dalam memenuhi kebutuhan informasi akademis. Selain itu juga penelitian ini bertujuan untuk:

1. Mengetahui bagaimana penggunaan media online dalam memenuhi kebutuhan informasi akademis dikalangan mahasiswa IISIP Yapis Biak.

2. Mengetahui media online apa saja yang menjadi sumber informasi akademis di kalangan mahasiswa IISIP Yapis Biak. 


\section{Manfaat Penelitian}

Adapun Manfaat dari penelitian ini adalah sebagai berikut:

1. Penelitian ini berguna dalam penambahan khasanah serta untuk melengkapi penelitian-penilitian terdahulu yang berhubungan dengan media online.

2. Penelitian ini berguna untuk akademisi dalam memanfaatkan media online sebagai salah satu sumber mendapatkan informasi akademis.

\section{TINJAUAN PUSTAKA}

Berkomunikasi merupakan keharusan bagi manusia.karena dengan berkomunikasi kebutuhan manusia akan terpenuhi. Menurut jhonson (1981) dalam (supratiknya , 2003: 9) mengemukakan beberapa peranan yang disumbangkan oleh komunikasi antar pribadi dalam rangka menciptakan kebahagian hidup manusia, adalah sebagi berikut:

1. Komunikasi antar oribadi membantu perkembangan intelektual dan sosiala kita.

2. Identitas atau jati dirikita terbentuk dalam dan lewat komunikasi dengan orang lain.

3. Dalam rangka memahami realitas di sekeliling kita serta menguji kebenaran kesan-kesandan pengertian yang kitamiliki tentang dunia di sekitar kita, kita perlu membandingkannya dengan kesankesan dan pengertian orang lain dengan realitas yang sama

4. Kesehatan mental kita sebagian besar juga ditentukan oleh kualitas komunikasi atau hubungan kita dengan orang lain , lebih-lebih orang yang merupakn tokoh-tokoh signifikan dalam hidupkita.

Pada dasarnya, manusia adalah mahluk yang memiliki ketergantungan dengan manusia lainnya, sehingga tidak dapat hidup secara mandiri, dan pasti membutuhkan orang lain untuk mengatasi kendala yang ada dalam kehidupannya, sehingga manusia biasa disebut sebagai makhluk sosial.

Dalam menjalani kehidupan sosial tersebut, seseorang memerlukan sebuah fasilitas serta cara, untuk membantunya mempermudah dirinya untuk masuk pada ranah hubungan komunikasi sosial tersebut. Interaksi merupakan ungkapan yang kemudian dapat menggambarkan cara untuk mempermudah terjadinya sebuah hubungan antara seseorang dengan orang lain, yang kemudian diaktualisasikan melalui praktek komunikasi, oleh karena itu, seringkali istilah komunikasi digantikan dengan komunikasi sosial, Komunikasi juga ditujukan untuk menyatukan komponenkomponen sosial yang bervariasi dan mempunyai prilaku yang berbeda.

Komunikasi adalah proses di mana pesan-pesan ditransfer dari sumber kepada penerima, baik secara langsung maupun melalui media. Memahami komunikasi berarti memahami apa yang terjadi selama komunikasi berlangsung, mengapa itu terjadi, manfaat apa yang dirasakan, akibatakibat apa yang ditimbulkan, apa tujuan dari aktivitas komunikasi, sesuai dengan apa yang diinginkan, memahami hal-hal yang dapat mempengaruhi dan memaksimalkan hasil-hasil dari kejadian tersebut.

A. Teknologi Informasi

Dan Komunikasi.

Teknologi Informasi adalah suatu teknologi yang digunakan untuk mengolah data, termasuk memproses, mendapatkan, menyusun, menyimpan, memanipulasi data 
dalam berbagai cara untuk menghasilkan informasi yang berkualitas, yaitu informasi yang relevan, akurat dan tepat waktu, yang digunakan untuk keperluan pribadi, bisnis, dan pemerintahan dan merupakan informasi yang strategis untuk pengambilan keputusan.

Teknologi ini menggunakan seperangkat komputer untuk mengolah data, system jaringan untuk menghubungkan satu komputer dengan komputer yang lainnya sesuai dengan kebutuhan, dan teknologi telekomunikasi digunakan agar data dapat disebar dan diakses secara global. Arti teknologi informasi bagi dunia pendidikan seharusnya berarti tersedianya saluran atau sarana yang dapat dipakai untuk menyiarkan program pendidikan. Pemanfaatan teknologi informasi dalam bidang pendidikan sudah merupakan kelaziman. Membantu menyediakan komputer dan jaringan yang menghubungkan rumah murid dengan ruang kelas, guru, dan administrator sekolah. Semuanya dihubungkan ke Internet, dan para guru dilatih menggunakan komputer pribadi.

Peran yang dapat diberikan oleh aplikasi teknologi informasi ini adalah mendapatkan informasi untuk kehidupan pribadi seperti informasi tentang kesehatan, hobi, rekreasi, dan rohani. Kemudian untuk profesi seperti sains, teknologi, perdagangan, berita bisnis, dan asosiasi profesi. Sarana kerjasama antara pribadi atau kelompok yang satu dengan pribadi atau kelompok yang lainnya tanpa mengenal batas jarak dan waktu, negara, ras, kelas ekonomi, ideologi atau faktor lainnya yang dapat menghambat bertukar pikiran.

\section{B. Internet Sebagai Media Komunikasi}

Studi ilmu komunikasi mencakup pembelajaran tentang media masa, dimana media masa diindonesiapada dasawarsa terahir ini mengalami perkembangan yang sangat pesat. Perubahan media masa, baik itu media masa elektronik mau pun media cetak, perlahan demi pasti mencapai titik dimana semua berubah formal menjadi digital.

Hal ini terlihat dengan adanya beberapa media masa cetak seperti majalah dan surat kabar yang mulai menerbitkan edisinya melalui World Wide Webnatau menyertakan CD ROM dalam setiap edisi yang diterbitkannya.

Bentuk perubahan pada lingkungan media banyak macamnya, dalam hal tertentu,sangat luar biasa. Di Indonesia televise berubah dari hanya satu stasiun TVRI pada tahun 80an menjadi sepuluh stasiun pada tahun 2000 yaitu TVRI, RCTI, SCTV, INDOSIAR, ANTV, TPI, TRANS TV, TRANS 7, GLOBAL TV, TV ONE . dan belum lagi ditambah dengan berbagai macam stasiun tv local yang banyak bermunculan di setiap kota besar, yang lebih mencengankang adalah adanya system tv kabel yang menagkap 50 saluran, bahkan bisa mencapai 500 atau lebih.

Penggunaan media lainnya yang tergolong baruseperti computer dan media internet mulai merambah di kalangan Indonesia, dari mulai anak-anak hingga orang dewasa dampaknya adalah orangorang menghabiskan lebih banyak waktunya berkomunikasi dengan orang lain dengan menggunakan ruang obrol (chat room) di computer, dan permainan dunia maya member dimensi pengalaman dan kepuasan baru bagi penggunanya.

Tapi apakah penggunaan internet memank dapat member manfaat positif atau malah dapat berdampak negative pada para penggunanya masih dapat belum dipastikan , sperti dijabarkan diatas ada banyak manfaat positif yang dapat dari pengguna media 
internet, tapi ada juga beberapa dampak negative yang dapat di alami oleh para pengguna internet.

Seperti yang di ketahui bahwa pengguna media internet dapat menelusuri apa aja yang diinginkannya, terlepas dari apakah hal tersebut member kontribusi positif bagi pengguna tersebut atau bahkan berdampak merusaknya moralitas penggunanya,

Sebagai contoh internet sebagai media komunikasi dapat terlihat pada sebuah web ataupun jejaring social seperti facebook,tweeter dan lain sebaigainya yang menawarkan berbagai layanan.

\section{Teknologi Informasi Dalam Pendidikan}

Jika dulu orang menempuh jarak ribuan $\mathrm{km}$ untuk mendapatkan informasi secara akurat, kini dapat ditempuh hanya dalam waktu beberapa detik saja melalui media internet. Kita dapat berkomunikasi dengan teman, maupun keluarga yang sangat jauh hanya dengan melalui handphone. Di era globalisasi ini segala sesuatu dituntut untuk serba praktis, cepat, dan tepat, maka dibutuhkan sarana dan prasarana yang dapat memenuhi hal tersebut, diantaranya dengan adanya sebuah teknologi informasi dan komunikasi yang mampu melayani dan memenuhinya. Dengan semakin globalnya kebutuhan manusia akan informasi dan komunikasi, maka diharapkan kepada masyarakat teknologi informasi dan komunikasi dapat dijadikan sebagai :

a. Sarana pelengkap dan pembantu dalam suatu proses kegiatan yang berjalan serba cepat dan tepat.

b. Alat bantu untuk mengambil, mengolah, menyimpan, dan menyajikan informasi dengan cepat, tepat, dan efisien.

c. Bahan referensi dari berbagai aspek kegiatan dan mampu memberikan sajian data yang sesuai dengan kebutuhan.

d. Teknologi informasi dan komunikasi merupakan wahana pembelajaran dan penyampaian materi pendidikan yang cepat, tepat, dan efisien.

Sebagai media pendidikan komunikasi dilakukan dengan menggunakan mediamedia komunikasi seperti telepon, komputer, internet, e-mail, dsb. Interaksi antara guru dan siswa tidak hanya dilakukan melalui hubungan tatap muka tetapi juga dilakukan dengan menggunakan mediamedia tersebut. Dengan adanya teknologi informasi sekarang ini guru dapat memberikan layanan tanpa harus berhadapan langsung dengan siswa. Demikian pula siswa dapat memperoleh informasi dalam lingkup yang luas dari berbagai sumber melalui cyber space atau ruang maya dengan menggunakan komputer atau internet. Hal yang paling mutakhir adalah berkembangnya apa yang disebut "cyber teaching" atau pengajaran maya, yaitu proses pengajaran yang dilakukan dengan menggunakan internet. Istilah lain yang makin poluper saat ini ialah e-learning yaitu satu model pembelajaran dengan menggunakan media teknologi komunikasi dan informasi khususnya internet. Elearning merupakan satu penggunaan teknologi internet dalam penyampaian pembelajaran dalam jangkauan luas yang belandaskan tiga kriteria yaitu: E-learning merupakan jaringan dengan kemampuan untuk memperbaharui, menyimpan, mendistribusi dan membagi materi ajar atau informasi. Pengiriman sampai ke pengguna terakhir melalui komputer dengan menggunakan teknologi internet yang standar. Memfokuskan pada pandangan yang paling luas tentang pembelajaran di 
balik paradigma pembelajaran tradisional. (Rosenberg 2001; 28)

Karenanya, dalam bahasan yang lain, Soekartawi (2003) mengidentifikasi bahwa keberhasilan implementasi e-learning sangat tergantung kepada penilaian apakah:

a. E-learning itu sudah menjadikan suatu kebutuhan;

b. Tersedianya infrastruktur pendukung seperti telepon dan listrik

c. Tersedianya infrastruktur pendukung seperti telepon dan listrik

d. Software pembelajaran (learning management system);

e. Kemampuan dan ketrampilan orang yang mengoperasikannya;

f. Kebijakan yang mendukung pelaksanaan program e-learning.

\section{Media}

Kegiatan komunikasi yang merupakan sebuah aktivitas rutin yang dilakukan oleh setiap orang maupun organisasi, tidak luput dari sebuah media yang digunakan dalam penyampaian pesan atau berita dari pengirim berita kepada penerima berita. Ada banyak ahli memberikan pengertian tentang media, Azhar Arsyad (2010: 3) mengatakan, "Kata Media berasal dari bahasa Latin medius yang secara harafiah berarti "tengah", "perantara" atau "pengantar". Dalam bahasa Arab, media adalah perantara atau pengantar pesan dari pengirim kepada penerima pesan." Sedangkan Arief (2009: 7) mendefinisikan:

Media merupakan segala sesuatu yang dapat digunakan untuk menyalurkan pesan dari pengirim ke penerima sehingga dapat merangsang pikiran, perasaan perhatian, dan minat serta perhatian siswa sedemikian rupa sehingga proses belajar terjadi.

Media komunikasi sangat penting dalam menunjang proses komunikasi, oleh karena media komunikasi dapat mempermudah penyampaian pesan, dan dapat mengatasi hambatan-hambatan komunikasi baik dari segi ruang maupun waktu. Dengan menggunakan media komunikasi, pimpinan dan karyawan perkantoran dapat dengan mudah melakukan interaksi dengan siapapun baik dengan orang lain dalam perkantoran yang sama maupun dengan orang lain di perkantoran yang berbeda. Suranto AW (2005: 121)

Media komunikasi ialah semua sarana yang dipergunakan untuk memproduksi, mereproduksi, mendistribusi atau menyebarkan dan menyampaikan informasi. Media komunikasi sangat diperlukan dalam operasional kerja suatu kantor karena media komunikasi dapat mempermudah penyampaian pesan, mengatasi hambatanhambatan komunikasi baik dari segi ruang maupun waktu.

Berdasarkan pendapat tersebut, media komunikasi merupakan semua sarana yang diperlukan untuk membuat,mengolah, hingga menyampaikan suatu pesan atau informasi. Media komunikasi sangat diperlukan sebagai alat yang dapat mempermudah penyampaian pesan. Dunia pendidikan seperti sekolah pun juga sangat membutuhkan suatu media komunikasi untuk penyampaian pesan kepada pihak didalam maupun diluarnya.

1. Pengertian Media Komunikasi Eksternal

2. Penggunaan Media Komunikasi Eksternal

\section{E. Pemanfaatan Media online}

Media online secara perlahan semakin berkembang, bahkan mungkin penemu sistem internet tidak terbayangkan bahwa perkembangan dunia internet sebegitu majunya apalagi yang telah terjadi 10 tahun 
belakangan ini. Tidak hanya improvisasi dalam bidang jaringan dan perangkat lunak (software) namun saat ini juga mulai banyak hadir improvisasi dalam bidang perangkat keras (hardware). Semua pengembang beranggapan bahwa apa yang meraka lakukan ini adalah untuk kehidupan masyarakat yang lebih baik.

\section{F. Uses And Gratifications.}

Teori Uses and Gratifications lebih menekankan pada pendekatan manusiawi dalam melihat media massa. Artinya manusia mempunyai otonomi, wewenang untuk memperlakukan media. Menurut pendapat teori ini, konsumen media mempunyai kebebasan untuk memutuskan bagaimana (lewat media mana) mereka menggunakan media dan bagaimana media itu akan berdampak pada dirinya (Nurudin, 2007:192).

Menurut Katz, Blumler \& Gurevitch (1974) dalam (Jalaluddin Rakhmat, 2005:205), menjelaskan mengenai asumsi dasar mengenai Teori Uses \& Gratifications, yaitu:

1. Khalayak dianggap aktif, artinya khalayak sebagaian penting dari penggunaan media massa diasumsikan mempunyai tujuan;

2. Dalam proses komunikasi massa, inisiatif untuk mengaitkan pemuasan kebutuhan dengan pemilihan media terletak pada anggota khalayak;

3. Media massa harus bersaing dengan sumber-sumber lain untuk memuaskan kebutuhannya. Kebutuhan yang dipenuhi media hanyalah bagian dari rentangan kebutuhan manusia yang lebih luas. Bagaimana kebutuhan ini terpenuhi melalui konsumsi media amat bergantung kepada perilaku khalayak yang bersangkutan Banyak tujuan pemilih media massa disimpulkan dari data yang diberikan anggota khalayak. Artinya, orang dianggap cukup mengerti untuk melaporkan kepentingan dan motif pada situasi-situasi tertentu.

4. Penilaian tentang arti cultural dari media massa harus ditangguhkan sebelum diteliti lebih dahulu orientasi khalayak.

Kita bisa memahami interaksi orang dengan media online melalui pemanfaatan media oleh orang itu (uses) dan kepuasan yang diperoleh (gratification). Gratifikasi yang sifatnya umum antara lain pelarian dari rasa khawatir, peredaan rasa kesepian, dukungan emosional, perolehan informasi, dan kontak sosial. (Nurudin, 2009:193)

\section{METODE PENELITIAN}

Penelitian merupakan cara ilmiah untuk mendapatkan data-data dengan tujuan tertentu. Dalam suatu penelitian penggunaan metode harus dapat mengarah pada tujuan penelitian agar hasil yang diperoleh sesuai dengan tujuan yang ingin dicapai.

Desain penelitian ini termasuk penelitian deskriptif dengan pendekatan kualitatif, karena penelitian ini ditujukan untuk mengungkap mengenai proses pelaksanaan komunikasi eksternal. Dalam penelitian ini menghasilkan penelitian data deskriptif berupa kata-kata tertulis atau lisan tentang orang-orang, perilaku yang dapat diamati sehingga menemukan kebenaran yang dapat diterima oleh akal sehat manusia.

\section{HASIL DAN PEMBAHASAN}

\section{A. Pentingnya Media Online Dalam Bidang Pendidikan}

Teknologi digunakan untuk mengatasi masalah, kendala, atau ketidakmampuan kita pada sesuatu. Sebagai contoh, ketika 
orang memiliki masalah dengan matanya, kita menggunakan teknologi yang berhubungan dengan optic untuk membuat kacamata. Demikian pula teknologi infor masi sebenarnya dapat digunakan untuk memecahkan masalah kita. Contoh lain, informasi melalui internet merupakan jendela dunia yang memberikan segala informasi yang ada di seluruh dunia. Satu klik pada mouse, kita dapat mengetahui berbagai informasi di penjuru dunia. Dengan informasi tersebut, kita dapat mengupdate pengetahuan kita. Dapat mempertimbangkan apa yang sebenarnya terjadi dan yang seharusnya terjadi. Dengan kemampuan pemikiran kita, bisa jadi kita menciptakan suatu pembaharuan atau inovasi kearah keadaan yang lebih baik. Terutama pada era globalisasi ini, persaingan tidak mungkin dapat dihindari. Kita harus menjadi seseorang yang peka terhadap teknologi, karena teknologi memberikan kita pembaharuan dan kemudahan.

Jika dulu orang menempuh jarak ribuan $\mathrm{km}$ untuk mendapatkan informasi secara akurat, kini dapat ditempuh hanya dalam waktu beberapa detik saja melalui media online. Kita dapat berkomunikasi dengan teman, maupun keluarga yang sangat jauh hanya dengan melalui handphone. Di era globalisasi ini segala sesuatu dituntut untuk serba praktis, cepat, dan tepat, maka dibutuhkan sarana dan prasarana yang dapat memenuhi hal tersebut, diantaranya dengan adanya sebuah teknologi informasi dan komunikasi yang mampu melayani dan memenuhinya. Dengan semakin globalnya kebutuhan manusia akan informasi dan komunikasi, maka diharapkan kepada masyarakat teknologi informasi dan komunikasi dapat dijadikan sebagai :
1. Sarana pelengkap dan pembantu dalam suatu proses kegiatan yang berjalan serba cepat dan tepat.

2. Alat bantu untuk mengambil, mengolah, menyimpan, dan menyajikan informasi dengan cepat, tepat, dan efisien.

3. Bahan referensi dari berbagai aspek kegiatan dan mampu memberikan sajian data yang sesuai dengan kebutuhan.

4. Teknologi informasi dan komunikasi merupakan wahana pembelajaran dan penyampaian materi pendidikan yang cepat, tepat, dan efisien.

Teknologi informasi serta Komunikasi dewasa ini berkembang cepat menurut deret ukur. Dari tahun ke bulan, dari bulan ke minggu, dari minggu ke hari, dari hari ke jam, dan dari jam ke detik. Oleh karena itulah para cerdik-cendekia sepakat pada suatu argumen, bahwa: informasi memudahkan kehidupan manusia tanpa harus kehilangan kehumanisannya.

Sebagai media pendidikan komunikasi dilakukan dengan menggunakan mediamedia komunikasi seperti telepon, komputer, internet, e-mail, dsb. Interaksi antara guru dan siswa tidak hanya dilakukan melalui hubungan tatap muka tetapi juga dilakukan dengan menggunakan media-media tersebut. Dengan adanya teknologi informasi sekarang ini guru dapat memberikan layanan tanpa harus berhadapan langsung dengan siswa. Demikian pula siswa dapat memperoleh informasi dalam lingkup yang luas dari berbagai sumber melalui cyber space atau ruang maya dengan menggunakan komputer atau internet. Hal yang paling mutakhir adalah berkembangnya apa yang disebut 
"cyber teaching" atau pengajaran maya, yaitu proses pengajaran yang dilakukan dengan menggunakan internet. Istilah lain yang makin poluper saat ini ialah e-learning yaitu satu model pembelajaran dengan menggunakan media teknologi komunikasi dan informasi khususnya internet. Elearning merupakan satu penggunaan teknologi internet dalam penyampaian pembelajaran dalam jangkauan luas yang belandaskan tiga kriteria yaitu: E-learning merupakan jaringan dengan kemampuan untuk memperbaharui, menyimpan, mendistribusi dan membagi materi ajar atau informasi. Pengiriman sampai ke pengguna terakhir melalui komputer dengan menggunakan teknologi internet yang standar. Memfokuskan pada pandangan yang paling luas tentang pembelajaran di balik paradigma pembelajaran tradisional. (Rosenberg 2001; 28)

Karenanya, dalam bahasan yang lain, Soekartawi (2003) mengidentifikasi bahwa keberhasilan implementasi e-learning sangat tergantung kepada penilaian apakah:

1. E-learning itu sudah menjadikan suatu kebutuhan;

2. Tersedianya infrastruktur pendukung seperti telepon dan listrik

3. Tersedianya fasilitas jaringan internet dan koneksi Internet;

4. Software pembelajaran (learning management system);

5. Kemampuan dan ketrampilan orang yang megoperasikannya;

6. Kebijakan yang mendukung pelaksanaan program e-learning.

E-learning pada hakikatnya adalah bentuk pembelajaran konvensional yang dituang dalam format digital dan disajikan melalui teknologi informasi. Secara ringkas, Anwas (2005) menyatakan e-larning perlu diciptakan seolah-olah peserta didik belajar secara konvensional, hanya saja dipindahkan ke dalam system digital melalui internet. Keunggulan- keunggulan elearning yang paling menonjol adalah efisiensinya dalam penggunaan waktu dan ruang. Seperti telah disebutkan di atas, pendidikan berbasis teknologi informasi cenderung tidak lagi tergantung pada ruang dan waktu. Tak ada halangan berarti untuk melaksanakan kegiatan belajar mengajar lintas daerah, bahkan lintas negara melalui e- learning. Dengan e-learning pengajar dan siswa tidak lagi selalu harus bertatap muka dalam ruang kelas pada waktu bersamaan.

Dengan sifatnya yang tidak tergantung pada ruang dan waktu, e-learning memiliki keunggulan lain yakni memungkinkan akses ke pakar yang tak terhalang waktu dan tak tidak memerlukan biaya mahal. Seorang pelajar di daerah dapat belajar langsung dari pakar di pusat melalui fasilitas internet chatting atau mengakomodir suara dan bahkan gambar realtime. Dengan e-learning, sekolah-sekloah dengan mudah dapat melakukan kerjasama saling menguntungkan melalui program kemitraan. Dengan demikian sekolah yang lebih maju dapat membantu sekolah yang belum maju sehingga dapat diupayakan adanya pemerataan mutu pendidikan. Satu lagi keunggulan e-learning tentunya adalah ketesediaan informasi yang melimpah dari sumber-sumber di seluruh dunia. Dengan menggunakan internet sebagi media pembelajaran akan didapatkan sumber informasi untuk pengayaan materi yang jumlahnya sangat tak terbatas.

B. Pengunaan Media Onlie Sebagai Sumber Informasi Akademik Pada Mahasiswa Iisip Yapis Biak Papua

Di kalangan mahasiswa IISIP Yapis Biak Papua, yang menjadi objek kajian 
penelitian ini, penggunaan internet sebagai media informasi dapat diklasifikasikan ke dalam tiga bentuk, yaitu: penggunaan web searching, penggunaan email, dan penggunaan e-learning.

\section{Web searching}

Fasilitas web searching di internet merupakan salah satu fasilitas yang paling lazim digunakan oleh para mahasiswa. Hasil angket menunjukkan bahwa $48 \%$ mahasiswa menggunakan internet untuk browsing mencari bahan yang berhubungan dengan materi perkuliahan, $40 \%$ menggunakannya untuk mencari informasi atau berita, dan sisanya, $12 \%$ menggunakannya sekedar sebagai hiburan atau mencari teman.

Bahkan, semua mahasiswa mengakui bahwa sebagian besar tugas-tugas dari dosen diselesaikan dengan bantuan internet (20\% menyatakan beberapa kali, 16\% kadang-kadang, dan $64 \%$ menyatakan selalu).

Tampaknya, fasilitas web searching di internet memberikan solusi yang mudah bagi mahasiswa untuk menyelesaikan tugas- tugas perkuliahan yang diberikan oleh dosen, apalagi jika tugas- tugas tersebut berupa makalah atau resume. Ketika mereka ditanya alasannya, jawaban yang diperoleh adalah: karena praktis (51\%), cepat (34\%), menarik (10\%), dan hanya sebagian kecil (5\%) yang beralasan karena selalu up to date.

Data ini menunjukkan bahwa ada kecenderungan mahasiswa menyelesaikan tugas-tugas perkuliahan secara instant melalui bantuan internet, sehingga tidak jarang terjadi praktek plagiasi makalah di kalangan mahasiswa. Internet, dengan demikian, tidak dijadikan sebagai alat bantu untuk mencari informasi terkini yang dapat memperkaya pengetahuan mareka tentang materi perkuliahan, melainkan sebagai sumber "barang jadi" berupa makalah atau resume yang dapat didownload langsung untuk memenuhi kewajiban yang dibebankan oleh dosen. Tidak heran jikamateri yang paling banyak diakses oleh mahasiswa terkait dengan bahan perkuliahan adalah: makalah mahasiswa dari perguruan tinggi lain (70\%), selebihnya Jurnal elektronik (7\%), Buku elektronik (5\%), dan pendapat para blogger (18\%).

Hal ini dipertegas dengan jawaban mahasiswa ketika ditanya tentang sumber utama yang menjadi rujukan dalam mempelajari materi perkuliahan.Sebagian besar dari mereka (73\%) menyatakan bahwa materi perkuliahan mereka pelajari melalui dosen dan buku paket, 20\% menambahkannya dengan buku penunjang lain, dan hanya $7 \%$ yang mencantumkan internet sebagai sumber penunjang dalam mempelajari materi perkuliahan.

Dengan demikian, motiv mahasiswa dalam penggunaan internet sebagai media pembelajaran, bukanlah untuk memperluas wawasan dan memperdalam pengetahuan, tetapi untuk memudahkan mereka dalam menyelesaikan tugas-tugas dari dosen. Tentu lebih praktis mendownload makalah atau resume yang sudah jadi dari internet, dibanding harus ke perpustakaan mencari bahan-bahan dan selanjutnya menyusun makalah sendiri.

Kondisi yang demikian tentu tidak mendidik, bahkan sebaliknya dapat mematikan kreativitas mahasiswa. Tidak jarang ditemukan mahasiswa yang mempresentasikan makalah di kelas tetapi tidak memahami isi makalahnya sendiri karena pada dasarnya makalah tersebut bukan hasil kerjanya melainkan hasil kerja orang lain yang didownload dari internet.

Menghadapi masalah ini, perlu strategi yang tepat dari setiap dosen agar mahasiswa 
dapat menjadikan internet sebagai salah satu media pembelajaran tanpa harus kehilangan kreativitas mereka. Dan yang terpenting, bagaimana membekali mahasiswa dengan kejujuran akademik sejak awal (mahasiswa baru), sehingga praktek plagiasi dari internet tidak membudaya.

\section{E-Mail}

Di samping fasilitas web searching yang paling dominan digunakan sebagai media informasi akademik di kalangan mahasiswa IISIP Yapis Biak, fasilitas e-mail juga menjadi salah satu media yang digunakan dalam proses informasi. Fasilitas ini biasanya digunakan oleh mahasiswa untuk berkomunikasi dengan dosen. $47 \%$ dari responden menyatakan bahwa mereka biasa berkomunikasi dengan dosen melalui email. Namun, saat ditelusuri lebih lanjut, bentuk komunikasi yang dimaksud masih terbatas pada penyetoran tugas-tugas perkuliahan (makalah) ke alamat e-mail dosen-dosen tertentu.

Di samping itu, tidak semua mahasiswa memiliki alamat e- mail. Terdapat $6 \%$ responden mengaku belum memiliki email, $45 \%$ menyatakan telah memiliki tapi jarang digunakan, dan hanya 49\% menyatakan telah memiliki dan selalu digunakan. Bagi mereka yang belum memiliki e-mail, biasanya menggunakan alamat e-mail temannya, atau alamat e-mail penyedia jasa rental internet apabila ada tugas-tugas yang harus dikirim kepada dosen.

Uraian di atas menunjukkan bahwa, bagi sebagian mahasiswa, memiliki alamat e-mail belumlah menjadi sebuah kebutuhan. Hal ini dapat disebabkan oleh beberapa faktor, antara lain: belum ada penekanan dari dosen agar mahasiswa mengirim tugas menggunakan alamat e-mail sendiri, e-mail jarang digunakan sebagai alat komunikasi karena sms dianggap lebih cepat dan memiliki jaringan yang lebih luas (tidak membutuhkan koneksi internet).

C. Faktor-Faktor Yang Berpengaruh Terhadap Penggunaan Media Online Sebagai Informasi Akademik Mahasiswa Iisip Yapis Biak Рapua

Minimnya penggunaan internet sebagai media informasi, tentu dipengaruhi oleh banyak hal yang secara garis besarnya dapat dipetakan ke dalam dua kategori utama, yaitu: faktor sarana-prasarana dan faktor sumber daya manusia.

Sarana dan prasarana pendukung penggunaan internet di kampus IISIP Yapis Biak terbilang cukup, meski belum memadai ditinjau dari segi kebutuhan pengguna yang begitu luas. Lembaga ini memiliki satu unit yang dikenal dengan ICT (Information and Communication Technology) yang bertanggung jawab penuh dalam mengelola sistem informasi dan komunikasi berbasis internet. Tugasnya antara lain, mengelola website kampus serta sistem administrasi akademik (Siakad) online. ICT memiliki ruang tersendiri sebagai ruang kerja para pengelolanya sekaligus sebagai tempat peralatan. Meski ruangan ini terlihat masih terlalu kecil untuk ukuran sebuah pusat kendali sistem komunikasi dan teknologi informasi kampus, tetapi sebagai langkah awal ruang ini sudah cukup efektif dalam menjalankan fungsinya.

Berdasarkan hasil observasi di lapangan, ditemukan bahwa hampir semua ruang perkuliahan (terutama lantai I dan II) di tiap program studi tidak memungkinkan untuk akses jaringan internet, terutama pada jam-jam perkuliahan. Sehingga, bila membutuhkan akses internet, mahasiswa biasanya harus mencari titik-titik tertentu 
di area kampus yang memiliki signal internet yang baik, misalnya, di depan ruang ICT atau di depan perpustakaan. Bahkan, pada Program Studi Pascasarjana yang memiliki jaringan internet sendiri melalui telkom-speedy, akses internet hanya bisa dilakukan di lantai I.

Berdasarkan hasil observasi di lapangan, ditemukan bahwa hampir semua ruang perkuliahan (terutama lantai I dan II) di tiap program studi tidak memungkinkan untuk akses jaringan internet, terutama pada jam-jam perkuliahan. Sehingga, bila membutuhkan akses internet, mahasiswa biasanya harus mencari titik-titik tertentu di area kampus yang memiliki signal internet yang baik, misalnya, di depan ruang ICT atau di depan perpustakaan. Bahkan, pada Program Studi Pascasarjana yang memiliki jaringan internet sendiri melalui telkom-speedy, akses internet hanya bisa dilakukan di lantai I.

Sarana pendukung lainnya bagi penggunaan internet sebagai media informasi adalah tersedianya komputer (laptop) untuk setiap dosen. Program pengadaan laptop bagi para dosen telah direalisasikan secara bertahap dan sudah berjalan lima tahap dalam lima tahun terakhir, sehingga sebagian besar dosen telah memiliki laptop sendiri yang disediakan oleh lembaga.

Namun, salah satu kekurangan yang dirasakan adalah belum tersedianya fasilitas komputer bagi mahasiswa. Sebagian besar mahasiswa belum memiliki komputer. Sedangkan pihak lembaga belum dapat menyediakan komputer umum yang dapat digunakan oleh mahasiswa secara gratis di tiap prodi. Ini merupakan kendala utama dalam penerapan informasi akademik berbasis internet,
Berdasarkan hasil angket diperoleh data bahwa hanya 23\% mahasiswa yang memiliki komputer (di rumah), 15\% yang memiliki laptop, dan $62 \%$ yang belum memiliki komputer. Belum lagi dari segi ketersediaan akses internet bagi mahasiswa di luar kampus, karena hanya 5\% mahasiswa yang memiliki modem sendiri, $23 \%$ menggunakan jasa warnet, dan sisanya memilih menggunakan jaringan internet di dalam kampus, baik dengan menggunakan komputer sendiri (26\%), atau komputer teman (46\%). Sungguh ironis, ternyata lebih banyak yang meminjam komputer teman dibanding yang memiliki komputer sendiri. Kondisi ini tentu sangat menyulitkan bagi kemungkinan penerapan internet sebagai media informasi akademik.

Faktor lain yang sangat berpengaruh terhadap penggunaan internet sebagai media informasi akademik adalah sumber daya manusia, baik dosen maupun mahasiswa. Peningkatan SDM dosen dibidang ICT telah dilakukan melalui pelatihan-pelatihan, baik yang dilakukan oleh Lembaga Penjaminan Mutu (LPM). Hingga saat ini, sebagian besar dosen telah menerima pelatihan di bidang penggunaan IT dalam pembelajaran, khususnya tentang e-learning melalui kegiatan Pelatihan Keterampilan Intstruksional (Pekerti) dan Applied Approach (AA). Sehingga secara teoritis, para dosen sebenarnya telah siap dalam mempraktekkan penggunaan internet sebagai media dalam informasi akademik.

Oleh karena itu, untuk penggunaan internet sebagai media informasi akademik, perlu dilakukan pelatihan bagi para mahasiswa. para mahasiswa telah dibekali dengan pengetahuan dan keterampilan di bidang IT sejak dini, misalnya, dirangkaikan dengan kegiatan OSPEK bagi 
mahasiswa baru. Materinya mencakup halhal yang berhubungan dengan pembelajaran berbasis internet, seperti pengenalan website yang bermuatan pendidikan (jurnal online, ebook, dll.), penggunaan perpustakaan digital, penggunaan program e-learning, dll.

\section{PENUTUP}

\section{A. Kesimpulan}

Berdasarkan uraian sebelumnya, berikut ini dipaparkan beberapa kesimpulan penelitian.

1. penggunaan internet sebagai media informasi akademik di IISIP Yapis Biak Papua dapat dipetakan ke dalam tiga kategori: penggunaan fasilitas web searching, penggunaan fasilitas e-mail, dan penggunaan fasilitas e-learning. Dari tiga kategori tersebut, yang paling dominan digunakan masih kategori pertama, web searching. Mahasiswa banyak menggunakan fasilitas ini dalam meyelesaikan tugas-tugas perkuliahan mereka, terutama dalam bentuk makalah dan atau resume. Sedangkan penggunaan e-mail umumnya hanya digunakan untuk mengumpulkan tugas-tugas kepada dosen yang kebetulan mempersyaratkan untuk itu, dan model ini pun tidak banyak yang menerapkannya. Selanjutnya, fasilitas e-learning paling sedikit digunakan, dalam hal ini hanya satu kasus yang ditemukan.

2. secara garis besarnya, faktorfaktor yang berpengaruh terhadap penggunaan media online sebagai media informasi akademik di IISIP Yapis Biak papua, ada dua, yaitu: sarana-prasarana dan sumber daya manusia. Dari segi saranaprasarana, aspek hardware yang dimiliki oleh ICT sudah cukup, tetapi besaran bandwidth yang dimiliki masih sangat jauh dari standar kebutuhan. Selanjutnya, dari segi sumber daya manusia, masih perlu peningkatan pengetahuan dan keterampilan di bidang IT bagi dosen dan mahasiswa untuk dapat menerapkan pembelajaran berbasis internet secara optimal.

3. mahasiswa IISIP Yapis Biak papua memberikan tanggapan yang sangat positif terhadap penggunaan internet sebagai media pembelajaran. Meski demikian, di sisi lain mereka masih mengeluhkan persoalan besarnya biaya yang harus ditanggung, terutama bagi mereka yang belum memiliki komputer sendiri dan atau akses internet pribadi, sementara jaringan internet di kampus masih sangat terbatas.

B. Saran

Berdasarkan dari penelitian yang dilakukan dan kemudian dipaparkan secara komprehensif pada bab sebelumnya, maka berikut adalah beberapa saran yang dapat peneliti sampaikan.

1. Bagi peneliti selanjutnya

Peneliti rasa akan menarik jika penelitian selanjutnya berfokus pada serpihan-serpihan yang ada pada penelitian ini semisal hal-hal yang berkaitan dengan kredibilitas media online untuk kebutuhan akademis atau melihat bagaimana perilaku antara pengguna media online dalam kehidupan sosialnya dalam 
memperlakukan informasi yang telah didapat.

2. Bagi dosen dan penulis artikel akademis

Peneliti harapkan untuk dapat mendorong pencarian informasi akademis dengan standard kualitas tinggi dengan mempertimbangkan aspek kredibilitas yang baik seperti tata letak, bentuk penulisan, sumber dan juga profile penulis agar dapat dipertanggung jawabkan dikemudian hari.

3. Bagi mahasiswa dan pembaca umum Melihat penggunaan media online seperti yang telah dijabarkan peneliti, maka sudi kiranya untuk memperhatikan dan mempertimbangkan aspek kredibilitas dalam menyadur informasi. Karena beberapa hal tersebut akan mempengaruhi kualitas informasi dari apa yang dituliskan kembali dan disebarkan, yang secara tidak langsung pula akan berdampak pada harga diri, martabat serta pandangan orang lain terhadap diri Anda.

\section{DAFTAR PUSTAKA}

Achmad, A.S, 1986. Aspek-Aspek Bunga Rampai Komunikasi II, Lembaga penelitian Universitas Hasanuddin, Ujung Pandang.

Cangara, Hafid. 2002. Pengantar Ilmu Komunikasi, Raja Grafindo.

Durkheim, Emil (Terjemahan Soerjono Sukanto)1986 Aturan-Aturan Metodologi Sosial, CV. Rajawali Jakarta.
Effendy, Onong Uchjan, 2002, Ilmu komunikasi Teori dan Praktek, Bandung Remaja Rosdakarya.

Fajar Junaedi, 2013. Komunikasi Politik, Teori, Aplikasi, dan Strategi Di Indonesia, Litera, Yogyakarta

Hall, Calvin S dan Gardner Lindzey. 1993 Psikologi Kepribadian 2 Teori-Teori Holistik

(OrganismikFenomenologis). Yogyakarta : Kanisius

Holmes, David, 2012, Teori Komunikasi, Media, Teknologi, dan Masyarakat, pustaka Pelajar, Yoyakarta.

Juniwati. (2007) Pemanfaatan Teknologi Informasi dalam Dunia Pendidikan.

Lister, Martin, Jon Dovey, dkk. 2009 New Media a Critical Introduction. Kanada : Routledge.

Littlejohn, Stepehen W dan Karen A. Foss. 2009 Teori Komunikasi Jakarta : Salemba Humanika.

Levenson, Paul. 2009. New Media. New York : penguin Academics

Lexy J, Meleong 2010. Metodologi Penelitian Kualitatif Bandung Remaja Rosdakarya.

Mulyana Deddy, 2000, Ilmu Komunikasi

Suatu Pengantar, PT Remaja Rosdakarya Bandung.

Miarso, Yusufhadi, 2005, Menyemai Benih Teknologi Pendidikan Kencana, Jakarta 2.

Nina, W.Syam, 2013, Model-Model Komunikasi, Simbiosa Rekatama Media, Bandung.

Nurudin. 2009. Pengantar Komunikasi Massa. Jakarta : Raja Wali Press 
Pawito. 2007. Penelitian Komunikasi Kualitatif, Yogyakarta LKIS

Rakhmat, Jalaludin. 2009. Psikologi Komunikasi. Bandung : Remaja Rosdakarya.

Syahputra, Iswandi dkk. 2006. Pengantar Ilmu Komuniksasi. Yogjakarta Pokja Akademis UIN Sunan kalijaga.

Sativa, Dian. 2010, Media online dan Pemenuhan Kebutuhan Informasi (Studi Korelasi Antara Aktivitas Menggunakan Media Online Dengan Pemenuhan Kebutuhan informasi di Kalangan Mahasiswa Jurusan Ilmu Komunikasi Swadana Transfer Angkatan 2008 Fisip UNS), Surakarta : Fisip, Universitas Sebelas Maret Surakarta.
Uchana Effendy , Onong. 2003. Ilmu Teori dan Filsafat Bandung : remaja rosdakarya.

Tahir Malik, Muh. 2009 Teori-teori Organisasi, Kretakupa Print, Makassar.

\section{JURNAL}

Novianto, lik 2011. Prilaku Penggunaan Internet di kalangan Mahasiswa ( studi Deskripsi Tentang prilaku Internet Di kalangan Mahasiswa Perguruan tinggi Fisip Unairi ) dengan perguruan tinggi UPN untuk memenuhi kebutuhan informasinya universitas Airlangga, Surabaya.

Soenhaji, Imam Martono dan Romdhoni S. 2008. Pemanfaatan media internet oleh mahasiswa sebagai media pencarian dan informasi. Depok : universitas Gunadarma 